\title{
Application Of The Domestic Production Activities Tax Deduction (Relating To A Wide Range Of Industries)
}

Martin A. Goldberg, (E-mail: mgoldberg@Newhaven.edu), University of New Haven Robert E. Wnek, (E-mail: rwnek@Newhaven.edu), University of New Haven Jonathan D. Leone, (E-mail: stockman2003@yahoo.com), University of New Haven Michael Rolleri, (E-mail: mrolleri@Newhaven.edu), University of New Haven

\begin{abstract}
Internal Revenue Code Section 199 is the domestic production activities deduction, which was enacted under the American Jobs Creation Act of 2004. This new deduction was to help compensate the repeal of the exterritorial income exclusion. Section 199 was intended to lower the tax burden on domestic manufacturers as well as to attract new investments in domestic manufacturing facilities. The deduction would yield tax breaks for certain types of businesses ranging large to small that predominately manufacture, produce, grow, or extract tangible personal property entirely or partially within the United States. The types of businesses, specifically, that will have an impact from Section 199 would be those in the film and sound recordings industries, companies in the construction business, and those in the field of architectural and engineering. In addition, those that qualified as doing business in any of the specific industries falling under Section 199 must be located and providing services in the United States. The Section 199 tax break will also benefit those in the business of producing electricity, natural gas, and water in the United States. The deduction is allowed to be taken for taxable years beginning after 2004, which creates many challenges. First, Section 199 establishes detailed tax concepts conditions, de minimis rules, exceptions, and safe harbors. Second, the deduction forces many businesses to implement new accounting systems to classify between qualifying and non-qualifying activities. All in all, this report explains how Section 199 works as well as benefits specific industries. However, important production eligibility issues remain in determining the production deduction for tangible property, which are the central items focused throughout this article. Furthermore, the research contain within, covers the guidance in Notice 2005-14, along with the proposed and final regulations to the rules under Section 199. An understanding of these rules will provide additional opportunities to qualify property and take advantage of tax breaks, yielding a better financial result to the taxpayer.
\end{abstract}

\section{INTRODUCTION}

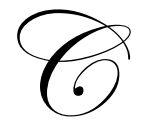

ongress introduced a new deduction relating to income attributable to U.S. manufacturing and production activities in 2004. This deduction was enacted under the American Jobs Creation Act ("AJCA") ${ }^{1}$. It is effective for taxable years beginning January 1, 2005, which is phased in over a six year period. The intention is to decrease the effective corporate tax rate from thirty-five percent to thirty-two percent. Prior to the enactment of AJCA, there were not any provisions under the current tax regime allowing a deduction for U.S. manufacturing and production activities. The deduction was to help reduce the tax burden on domestic manufacturers.

\footnotetext{
${ }^{1}$ P.L. 108-357 was issued on October 22, 2004.
} 
Legislators were spurred to enact this new deduction due to the repeal of the extraterritorial income exclusion ("ETI") system, effective for transactions occurring after December 31, 2004. Furthermore, as part of the repeal provisions, the AJCA granted phase-out and binding contract exceptions, which will continue to provide ETI benefits for taxable years 2005 and 2006, respectively. The unexpected benefit under the AJCA is that taxpayers who may be subject to the ETI phase-out provisions can still qualify for the deduction during taxable years 2005 and 2006. This was to ensure that the phase-out provisions of the ETI would not be a factor in limiting those qualifying for the deduction.

The ETI system was originally set-up to replace the foreign sales corporation ("FSC") method. Like many other countries, the United States has long provided export-related benefits under the IRC. For the past two decades, these benefits were provided under the FSC. The FSC was created to promote the export of property that was manufactured in the United States ${ }^{2}$. FSCs were labeled as foreign corporate subsidiaries of U.S. domestic companies whose purpose was to export goods manufactured in the United States ${ }^{3}$. As a result, the rules allowed a percentage of an FSC's income earned from the sale of qualified export property to be exempt from U.S. income taxation ${ }^{4}$. Furthermore, any corporate stockholders receiving such dividends attributable to exempt FSC income, as well as aftertax nonexempt FSC income, were permitted to take a deduction". In 2000, the World Trade Organization ("WTO") declared the FSC regime as a prohibited export subsidy. In response to this WTO finding, the U.S. repealed the FSC rules and enacted a new regime, under the FSC Repeal and Extraterritorial Income Exclusion Act of 2000. Under ETI, taxpayers were allowed to take a deduction for a portion of their income from exports; specifically, an exclusion from the taxpayer's gross income attributable to foreign gross receipts. As a result, this income was eligible for the exclusion to the extent there was qualifying foreign income. In spite of this, in January of 2002, the WTO declared the ETI system also constituted a prohibited export subsidy because the system violated international trade agreements.

The two systems, the FSC and ETI, originally set-up to help compete with foreign competitors to provide taxpayers incentives to sell goods in foreign markets had now been repealed. This generated momentum for a replacement to 1) help compensate the loss of the export incentives, 2) keep U.S. manufacturing and production activities and processes being sent abroad in order to encourage U.S. based production activities (which was viewed as being exposed to anti-competitive foreign subsidies), and 3) regain new manufacturing businesses from abroad (e.g., making investments in domestic manufacturing facilities more attractive). Congress acknowledged it had not decreased the corporate income tax rates since $1986^{6}$. In addition, existing high corporate income tax rates impeded the ability of U.S. corporations "to attract and retain economically vibrant industries, which create good jobs and contribute to overall economic growth." Therefore, AJCA incorporated the domestic production activities deduction as a new incentive for U.S. production.

The production incentive, which has been added in the Internal Revenue Code ("IRC") designated as Section $199^{8}$, explains many key provisions in the U.S. tax policy. The first provision created two (2) types of U.S. income: 1) qualified production activities income ("QPAI") and 2) all other income. As a result, mandatory computation for the two (2) separate categories of income is necessary. Each income category will be taxed at different marginal rates due to a special deduction pertaining only to QPAI. Therefore, starting for taxable years beginning in 2005 through 2006, taxpayers will be permitted to take an additional deduction worth three percent ("3 \%") of their QPAI as opposed to no additional deduction for non-QPAI (e.g., all other income). For taxable years beginning, however, in 2007, 2008, and 2009 the deduction doubles to six percent ("6 \%") on QPAI. When fully phased in by 2010 , the deduction will be worth nine percent ("9 \%") on QPAI, resulting in an effective tax rate of thirty-two percent ("32\%") on QPAI as opposed to the highest marginal rate of thirty-five percent (" $35 \%$ \%) on non-QPAI (e.g., all other income).

\footnotetext{
${ }^{2}$ CCH Standard Federal Income Tax Reporter, Explanation of Foreign Sales Corporation rules (CCH) I[28,085.01.

${ }^{3}$ AJCA - Law, Explanation and Analysis (CCH 2004), II 205.

${ }^{4}$ CCH Standard Federal Income Tax Reporter, supra note 2.

${ }^{5} \mathrm{Id}$.

${ }^{6}$ Conference Committee Report (H.R. Conf. Rep. No. 108-755) to Act Sections 102(a) and (b).

${ }^{7} \mathrm{Id}$.

${ }^{8}$ All citations to "Section" are referring to the Internal Revenue Code ("IRC") of 1986, as amended, unless otherwise stated.
} 
Overall, Congress recognized manufacturers and producers faced major challenges during the nation's recent economic slowdown. In addition, Congress was concerned about the adverse competitive impact of foreign markets on U.S. manufacturers and producers. ${ }^{9}$ As a result of these concerns, Congress has significantly broadened the definition of manufacturing to include an array of new types of U.S. businesses, enabling a wide range of industries to benefit from the new deduction. These industries include construction companies, architectural and engineering firms, software creators, sound recording and film producers, power generators, production of certain natural resources, and other taxpayers that derive income from qualified production activities performed in the United States.

Section 199 will provide over $\$ 76$ billion in tax relief for qualified U.S. based production over the next ten years for domestic manufacturers and producers. To be eligible for this tax relief, income must be derived from domestic production activities completed in the U.S. and/or manufacturing processes performed for activities within the U.S. The deduction was not geared to benefit only very large businesses; it benefits many smaller companies as well ${ }^{10}$.

Other benefits of the manufacturing deduction include the following: 1) the manufacturing deduction, allowed for regular tax purposes, can also be used in calculating alternative minimum tax ("AMT"). 2) Special rules exist in applying the deduction on pass-through entities. Pass-through entities, such as S corporations, partnerships, estates, or trusts, is determined and claimed at the owner level. The deduction is only available for pass-through entity years starting on or after January 1, 2005. As a result, the deduction has an effect on the business structure and operations of those entities involved in the domestic production activities on U.S. manufacturing processes.

The article will examine the fundamentals of the Section 199 domestic production activities deduction enacted under the AJCA, taking a look at what types of industries that will be affected by this new deduction, and finally examining how the deduction affects pass-through entities. Lastly, the Department of Treasury and the Internal Revenue Service ("IRS") provided guidance on the Section 199 manufacturing deduction in three important reports: 1) in the form of Notice 2005-14 ${ }^{11}$ in January of 2005, 2) provisions of the final regulations on June 1, 2006, and 3) in the Tax Increase Prevention and Reconciliation Act on May 17, $2006^{12}$.

\section{FUNDAMENTALS OF THE DOMESTIC PRODUCTION ACTIVITIES DEDUCTION}

The U.S. domestic production activities deduction is being phased in over a six (6) year period effective for taxable years commencing after December $31,2004^{13}$. Taxpayers that meet the criteria for the deduction will be permitted a deduction equal to qualified income multiplied by the applicable percentage. Over the six (6) years, there will be an increase in the applicable deduction percentage. In the first two years of the deduction, the maximum deduction percentage for taxable years beginning in 2005 and 2006 will be three percent ("3\%"). For later taxable years starting 2007 through 2009, the applicable percentage increases from 3\% to six percent ("6 \%"). Finally, for taxable years beginning in 2010 and beyond, the deduction will be nine percent ("9 $\%$ ") ${ }^{14}$. The deduction is further limited to fifty percent (" $50 \%$ ") of the W-2 wages that the taxpayer paid during the taxable year ${ }^{15}$. The sum of these wages is the aggregate amounts reported on Form W-2 for employees, such as compensation subject to withholding and elective deferrals ${ }^{16}$. In determining net earnings from self-employment, the deduction is not allowed to be taken

\footnotetext{
${ }^{9}$ Conference Committee Report, supra note 6.

${ }^{10}$ CCH Federal Tax Weekly, Issue Number 4, Jan. 27, 2005.

11 2005-7 I.R.B. 498 was issued on January 19, 2005. The guidance will be referred to hereon as "Notice 2005-14." References to any parts of Notice 2005-14 will be cited by explicit sections (" $§$ ") from the Notice.

12 P.L. 109-222.

${ }^{13}$ IRC Section 199, added by the American Jobs Creation Act of 2004 (“AJCA”), P.L. 108-357, §102.

${ }^{14}$ IRC Section 199(a)(1) \& (a)(2)

${ }^{15}$ IRC Section 199(b)(1).

${ }^{16}$ IRC Sections 6051(a)(3) \& (a)(8).
} 
into consideration ${ }^{17}$. For individual taxpayers, the taxable income amount is adjusted gross income ("AGI"), with modifications for the taxable year ${ }^{18}$.

Under Section 199, the applicable percentages from above are applied to the lesser of two (2) qualified income amounts ${ }^{19}$. These two amounts are either 1) qualified production activities income ("QPAI") $)^{20}$ or 2) taxable income, which is determined without taking into account the Section 199 deduction $^{21}$.

\section{Example}

$\mathrm{ABC}$, Inc. ("ABC"), a U.S. corporation and not part of an expanded affiliated group, is in the business of manufacturing activities that generated QPAI and taxable income of $\$ 10,000$ in 2005, before the calculation of Section 199 deduction. During 2005, ABC paid wages of \$5,000. In addition, ABC has a net operating loss ("NOL") carryover to 2005 of $\$ 9,000$. ABC's Section 199 deduction for 2005 is $\$ 30$. The deduction is calculated as follows:

The applicable deduction percentage in 2005 is $3 \%$. 3\% is multiplied by the lesser of: QPAI of $\$ 10,000$; Taxable income of $\$ 1,000$ ( $\$ 10,000$ taxable income - $\$ 9,000 \mathrm{NOL}$ carryover). Thus, 3\% x $\$ 1,000$ taxable income equals $\$ 30$ as a Section 199 deduction for $\mathrm{ABC}$ in $2005 .^{22}$

In the example above, the wage limitation is $\$ 2,500$ ( $\$ 5,000$ of wages paid in $2005 \times 50 \%$ ). The deduction is also subject to the wage limitation ( $\$ 5,000$ of wages paid in $2005 \times 50 \%$ ). If wages paid in 2005 was zero ( $\$ 0$ ), in the example above, the deduction for 2005 would be zero $(\$ 0)$.

Starting in 2005, the deduction is available for calendar year taxpayers. However, the Section 199 deduction will not be eligible for fiscal year taxpayers until its taxable year ending in $2006^{23}$. For taxable years beginning before June 1, 2006, QPAI is computed on an item-by-item basis and not by division, production line, or transactional basis as expressed in the rules of Notice 2005-14.24. Under the final regulations, beginning June 1, 2006 and thereafter, this rule will not apply due to the inconsistency between the item-by-item methodology and the cost allocation methods prescribed by the Treasury in determining whether gross receipts are domestic production gross receipts ("DPGR"). Under the old rule, all items of QPAI are to be netted in the calculation of the deduction ${ }^{25}$. If a taxpayer only manufactures qualifying production property, which is computer software, sound recordings as described under Section 168(f)(4) of the IRC, or tangible personal property, the taxpayer's QPAI will be equal to its taxable income during the taxable year. In view of the fact that this may not often be the case, the objective beyond calculating a correct deduction is to properly allocate income, expenses, losses, and deductions to items for determining QPAI

\footnotetext{
${ }^{17}$ IRC 1402(a)(16), added by the AJCA of $2004 \S 102$.

${ }^{18}$ IRC Section 199(d)(2); Regs. $\$ 1.199-1(b)(1)$. The individual taxpayer's AGI for the taxable year is computed after employing IRC Sections 86, 135, 137, 219, 221, 222, and 469. Section 199, on the other hand, is not allowed to be taken into consideration when figuring a taxpayer's AGI for the taxable year. For taxable years after June 1, 2006, however, any amount that is excluded from gross income under former IRC Section 114 or AJCA Section 101(d) are also not permitted to be taken into consideration when coming up with the amount as being the taxpayer's overall AGI for the taxable year.

${ }^{19}$ IRC Section 199(a)(1); Regs. §1.199-1(a).

${ }^{20}$ IRC Section 199(a)(1)(A).

${ }^{21}$ IRC Section 199(a)(1)(B); Regs. §1.199-1(b)(1).

${ }^{22}$ Regs. $\$ 1.199-1(\mathrm{~b})(2)$, Ex. 1.

${ }^{23}$ IRC Section 199(d)(1)(A)(i) states that Section 199 deduction is determined at the owner level, which this concept pertains to pass-through entities where items attributable to qualifying production activities of the pass-through entity pass-through to the owner according to the economic arrangement of the owners. Thus, if a partnership or an S corporation has a fiscal year end versus a calendar year end and QPAI with calendar year partners or shareholders, the partners or shareholders will not be permitted to claim the Section 199 deduction passing from the partnership or S corporation until the partners' or shareholders' 2006 calendar year end since the pass-through entity's fiscal year beginning after 2004 will include income from the year in which the deduction was made available. Notice $2005-14, \S 4.06(3)$.

${ }^{24}$ Notice 2005-14, §4.03(1); Former Prop. Regs. §1.199-1(c)(1).

${ }^{25}$ The intention beyond this rule is to have all items included in the calculation instead of having the taxpayer selecting only profitable items in the computation of QPAI.
} 
regardless of whether DPGR exceeds its related cost of goods sold and deductions allocated as well as apportioned to DPGR $^{26}$.

QPAI is determined as being equal to the excess of DPGR less the net cost of domestic production for the taxable year ${ }^{27}$. In computing the net cost of domestic production, the IRC enforces a single category for DPGR ${ }^{28}$. The cost of domestic production is the sum of the cost of goods sold ("COGS") that is allocable to the receipts consisting of DPGR; and other expenses, losses, and deductions (other than the Section 199 deduction), which are properly allocable to those receipts ${ }^{29}$. Proper allocable items include selling and marketing expenses, and other general and administrative expenses, which can be properly allocable to DPGR ${ }^{30}$.

Under Section 199, the IRC defines DPGR as gross receipts derived from a principal business involved in any lease, rental, license, sale, exchange, or other disposal of qualifying production property ("QPP"), which was manufactured, produced, grown, or extracted ${ }^{31}$ in whole or in substantial part ${ }^{32}$ within the United States ${ }^{33}$. This also includes (a) gross receipts coming from the sale, exchange, or other disposal of agricultural products in which the taxpayer performs storage, handling, or other processing activities, with the exception of transportation activities within the United States, if the products are used in connection with, or incorporated into, the manufacturing, production, growth or extraction of QPP by the taxpayer or another party ${ }^{34}$; (b) any qualified film produced by the taxpayer $^{35}$; or (c) electricity, natural, gas, or portable water produced by the taxpayer within the United States ${ }^{36}$. Additionally, Section 199 broadens the definition of DPGR to include the following gross receipts from construction of real property performed in the United States by a taxpayer that is engaged in the ordinary course of a trade or business conducting construction activities ${ }^{37}$. This also includes engineering or architectural services performed in the United States ${ }^{38}$.

Section 199 further defines QPP as any tangible personal property, computer software, films, and certain sound recordings produced in the U.S. ${ }^{39}$ The meaning of "tangible personal property", for purposes of the manufacturing deduction, is any tangible property, excluding land and improvements thereto, such as buildings or other inherently permanent structures ${ }^{40}$. Any property categorized as tangible personal property will consequentially be eliminated as being considered computer software, sound recordings, or qualified films.

DPGR, under Section 199, excludes: 1) gross receipts derived from a trade or business where the sale of food and beverages are prepared at a retail establishment ${ }^{41}$. 2) Any gross receipts solely from either transmitting or

\footnotetext{
${ }^{26}$ Former Prop. Regs. $\$ 1.199-1(\mathrm{c})(1)$. The sum of QPAI calculated by the taxpayer can either be a positive or negative figure.

${ }^{27}$ IRC Section 199(c)(1); Regs. \$1.199-1(c).

${ }^{28}$ IRC Section 199(c)(1)(B)(ii), as amended by GO Zone Act of 2005, §403(a)(3); Regs. §1.199-1(c).

${ }^{29}$ IRC Section 199(c)(1)(B), as amended retroactively by the GO Zone Act of 2005, P.L. 109-135, §403(a)(3). This also clarifies that the domestic production activities deduction itself is not an allocable deduction when figuring QPAI.

${ }^{30}$ H.R. Conf. Rep. No. 108-755.

${ }^{31}$ Regs. §1.199-3(f)(1).

${ }^{32}$ Regs. $\$ 1.199-3(\mathrm{~g})$.

${ }^{33}$ IRC Section 199(c)(4)(A)(i)(I); Regs. §1.199-3(a) \& (h).

${ }^{34} I d$.

${ }^{35}$ IRC Section 199(c)(4)(A)(i)(II); Regs. §1.199-3(a)(1).

${ }^{36}$ IRC Section 199(c)(4)(A)(i)(III); Regs. §1.199-3(a)(1).

${ }^{37}$ IRC Section 199(c)(4)(A)(ii), as amended by the 2005 Gulf Opportunity Zone Act (“GO Zone”), P.L. 109-135, §403(a)(5). In order to be recognized in the trade or business of construction, the GO Zone requires that the taxpayer be engaged in the active conduct of construction project endeavors. Further, the taxpayer has to be engaged in such endeavors on a regular and ongoing basis; Regs. §1.199-3(a).

${ }^{38}$ IRC Section 199(c)(4)(A)(iii), as amended by the 2005 Gulf Opportunity Zone Act ("GO Zone), P.L. 109-135, §403(a)(5). In order to be recognized in the trade or business of engineering or architectural services, the GO Zone requires that the taxpayer be engaged in the active conduct of services performed with respect to the construction of real property project endeavors in the U.S. Further, the taxpayer has to be engaged in such endeavors on a regular and ongoing basis; Regs. \$1.199-3(a).

${ }^{39}$ IRC Section 199(c)(5). This also includes any property described in IRC Section 168(f)(4).

${ }^{40}$ IRC Section 199 borrows the definition of "tangible personal property” from Treasury Regulations ("Regs.") Section 1.48-1(c).

${ }^{41}$ IRC Section 199(c)(4)(B)(i); Regs. §1.199-3(o)(1).
} 
distributing electricity, natural gas, or potable water ${ }^{42}$. However, if the taxpayer is an integrated producer that generates electricity, produces natural gas, or potable water as well as delivers those items to the end users, any gross receipts attributable to the transmission of those items from the producing facility to a point of local distribution and delivery of these items to the customers are not DPGR ${ }^{43}$. 3) Taxpayers who lease, rent, license, sell, exchange, or dispose of QPP for use by any related party ${ }^{44}$. Persons are "related" if they are members of a controlled group of corporations or an affiliated service group, or are other entities under common control ${ }^{45}$. The exclusion will not apply to the taxpayer if the QPP or qualified film being leased, rented, or licensed to the related party will ultimately be reproduced and sold, exchanged, leased, rented, or sublicensed to an unrelated person for the sole consumption of the unrelated party ${ }^{46} .4$ ) Those in the business of leasing, renting, licensing, selling, exchanging, or disposition of land ${ }^{47}$.

As previously stated, the amount of the deduction cannot exceed fifty percent ("50\%") of W-2 wages paid to employees and reported by the taxpayer during the taxable year ${ }^{48}$. Before determining what or if any wages qualify for the $50 \%$ limitation there first has to be an actual conduct of a trade or business (e.g., a trade or business requirement $)^{49}$. A taxpayer engaged in an actual conduct of a trade or business must take into account in computing QPAI only items that are attributable to that trade or business (or trades or businesses) and any items allocated from a pass-through entity engaged in a trade or business. An individual employee receiving a salary or wages for services performed as an employee is not considered gross receipts for purposes of computing QPAI. Likewise, any costs or expenses paid or incurred by an individual employee with respect to those services performed as an employee are not considered COGS or deductions of that employee for purposes of computing QPAI ${ }^{50}$.

The taxpayer must include wages paid to all employees in the taxable year and not just the wages of employees engaged in QPAI when determining the amount of W-2 wages. However, beginning after May 17, 2006, the deduction is further limited to $50 \%$ of wages allocable to DPGR. The wages allocable to DPGR are the wages deducted in arriving at $\mathrm{QPAI}^{51}$. The meaning of W-2 wages for purposes of Section 199 is the total amount of wages and elective deferrals that the taxpayer must include and report on statements with respect to the employees working for the taxpayer ${ }^{52}$ during the taxable year ${ }^{53}$. The W-2 wages are typically those that have been issued at calendar year end for wages paid during the taxpayer's taxable year ${ }^{54}$. Since Form W-2 has no single box that meets the definition of W-2 wages for Section 199, the taxpayer has three (3) alternative methods to calculate W-2 wages outlined by the Internal Revenue Service ("IRS") $)^{55}$. Any of the three (3) methods used listed below has a stipulation in the final regulations regarding a non-duplication rule. The rule states that an amount treated as W-2 wages for a taxable year

42 IRC Section 199(c)(4)(B)(ii); Regs. §1.199-3(1)(4).

${ }^{43}$ Footnote 28 of the Conference Committee Report No. 108-755 under Sections 102(a) and (b) of the ACJA of 2004; Section 3.04(10(a) of Notice 2005-14; Regs. §1.199-3(1)(4); former Prop. Regs. §1.199-3(k)(4)

${ }^{44}$ IRC Section 199(c)(7)(A) \& (B); Regs. §1.199-3(b).

${ }^{45} \mathrm{Id}$.

${ }^{46} I d$.

${ }^{47}$ IRC Section 199(c)(4)(B)(iii), as amended retroactively by the GO Zone Act of 2005, P.L. 109-135, §403(a)(6); Regs. §1.199$3(\mathrm{~m})(6)(\mathrm{iii})$.

${ }^{48}$ IRC Section 199(b)(1), as amended retroactively by the GO Zone Act of 2005, P.L. 109-135, §403(a)(1).

${ }^{49}$ Regs. §1.199-8(c)(1).

${ }^{50}$ Regs. $\$ 1.199-8(\mathrm{c})(2)$. A trust or estate is treated as an individual, see Regs. $\$ 1.199-8(\mathrm{c})(3)$.

${ }^{51}$ IRC Section (b)(2)(B), as being integrated by the Tax Increase Prevention and Reconciliation Act of 2005 ("TIPRA"), P.L. 109$222, \S 514$.

52 Regs. $\$ 1.199-2(a)(1)$. In the context of taxpayer above means employer. Thus, W-2 wages are limited to wages paid to employees under common law rules and not corporate officers that are actually reported on Forms W-2.

${ }^{53}$ IRC Section 199(b)(2)(A); Regs. §1.199-2(e)(1).

${ }^{54}$ Regs. $\$ 1.199-2(\mathrm{a})(1)$.

${ }^{55}$ Rev. Proc. 2006-22; see former Prop. Regs. §1.199-2(f)(2). For taxable years beginning on or before May 17, 2006, a taxpayer has the choice to apply Rev. Proc. 2006-22 along with the Final Regulations under 1.199-1 through 1.199-9 or the guidance contained in Notice 2005-14 and the Proposed Regulations under Section 1.199-2. However, for taxable years beginning after May 17, 2006, but before June 1, 2006, a taxpayer is not permitted to apply any of the rules contained in Notice 2005-14, the Proposed Regulations, or any other guidance under IRC Section 199 since they may be inconsistent to the amendments added by the Tax Increase Prevention and Reconciliation Act ("TIPRA"), P.L. 109-222, §514. 
shall not be treated as W-2 wages of any other taxable year ${ }^{56}$. Further, an amount shall not be treated as W-2 wages by more than one taxpayer ${ }^{57}$.

The first method is the unmodified box method. Under this method, W-2 wages are computed by taking, without regard to any adjustments, the lesser of the total amounts in Box 1 or Box 5 of all Forms W-2 filed with the Social Security Administration ("SSA") by the taxpayer or employer respect to the employees working for the taxpayer $^{58}$. The second method is the modified Box 1 method. With this method, the taxpayer or employer makes adjustments to the total amounts in Box 1 of Forms W-2 filed. To calculate W-2 wages under this method, the taxpayer has to: 1) total the amounts in Box 1 of all Forms W-2 with respect to employees working for the company. 2) From that sum, subtract amounts included in Box 1 that are not wages for federal income tax withholding purposes and amounts included in Box 1 are treated as wages for purposes of federal income tax withholding ${ }^{59}$. 3) From the resulting amount obtained in the second step, add amounts that are reported in Box 12 of Forms W-2 with respect to employees working for the company and are properly coded D, E, F, G, or $\mathrm{S}^{60}$. The third and final method the taxpayer or employer can use is called the tracking wages method. The taxpayer or employer actually tracks total wages subject to federal income tax withholding along with making the appropriate and applicable adjustments. The rules for using this method are as follows: 1) Add the wages subject to federal income tax withholding that are paid to employees of the company for employment and are reported on all Forms W-2 for the calendar year. 2) From that sum in step one; subtract any supplemental unemployment compensation benefits ${ }^{61}$ that may be contained in the total from the preceding step. 3) From the resulting amount in the second step, total the amounts that are reported in Box 12 of all Forms W-2 with respect to employees of the company for employment and are properly coded D, E, F, G, or $\mathrm{S}^{62}$.

In the case of a taxpayer with a short taxable year, the W-2 wages are calculated using the tracking wages method as described above ${ }^{63}$. Whatever method the taxpayer wishes to choose or elect, the taxpayer has to report compensation paid to common law employees on Form W-2 with the Social Security Administration ("SSA") no later than sixty ("60") days after the extended due date of the form ${ }^{64}$.

A taxpayer's losses and deductions that otherwise would be taken into consideration must be applied to taxable income before calculating the Section 199 deduction. The deduction is taken into account only if and to the extent it is not disallowed by the at-risk rules ${ }^{65}$, passive activity loss rules ${ }^{66}$, or any other IRC provision. If a portion of the taxpayer's share of the losses or deductions is allowed for a specific taxable year, the proportionate share of the allowable losses or deductions allocated to the taxpayer's qualified production activities is taken into account in calculating QPAI for that taxable year. To the extent any disallowed losses or deductions are allowed in later taxable years, the taxpayer takes into consideration a proportionate share of the losses or deductions in computing QPAI for that later taxable year ${ }^{67}$. The treatment of net operating losses ("NOLs") must be applied to taxable income before computing the Section 199 deduction as well. A deduction for a NOL ${ }^{68}$ is not allocated or apportioned to DPGR or gross income attributable to $\mathrm{DPGR}^{69}$. If a taxpayer is planning to take the Section 199 deduction for any given taxable year and also has either currently incurred an NOL or an NOL has been carried forward from previous years, which

\footnotetext{
${ }^{56}$ Regs. §1.199-2(d); see former Prop. Regs. §1.199-2(e).

${ }^{57}$ Id.

${ }^{58}$ Rev. Proc. 2006-22, 2006-23 I.R.B., §5.01; see former Prop. Regs. §1.199-2(f)(2)(i).

${ }^{59}$ As described under IRC Section 3402(o).

${ }^{60}$ Rev. Proc. 2006-22, 2006-23 I.R.B., \$5.02; see former Prop. Regs. §1.199-2(f)(2)(ii).

${ }^{61}$ As described under IRC Section 3402(o)(2)(A).

${ }^{62}$ Rev. Proc. 2006-22, 2006-23 I.R.B., §5.03; see former Prop. Regs. §1.199-2(f)(2)(iii).

${ }^{63}$ Rev. Proc. 2006-22, 2006-23 I.R.B., \$6.02; see former Prop. Regs. \$1.199-2(c).

${ }^{64}$ IRC Section 199(b)(2)(C), as amended retroactively by the GO Zone Act of 2005, P.L. 109-135, §403(a)(2), along with as being redesigned by TIPRA §514; Regs. §1.199-2(a)(3)(i).

${ }^{65}$ IRC Section 465.

${ }^{66}$ IRC Section 469.

${ }^{67}$ Regs. $\$ 1.199-8(\mathrm{~h})$.

${ }^{68}$ IRC Section 172.

${ }^{69}$ Regs. $§ 1.199-4(c)(2)$.
} 
can be used in that year, may not be able to take the Section 199 deduction ${ }^{70}$. Moreover, when an NOL carry back is being applied in the same taxable year the taxpayer may wind up losing some of the benefit from this new deduction. As a result, an NOL that has been either: 1) currently incurred in a taxable year, 2) carry back, or 3) carry forward can play a huge part on one's planning ability to be eligible to take the Section 199 deduction.

\section{ACCOUNTING ISSUES AND PRACTICAL MATTERS IMPLEMENTING SECTION 199}

The pitfall of the deduction is the requirements of allocating costs to jobs and projects performed in the United States. Time has to be set aside to reasonably identify from the books and records, costs and expenses directly attributable to DPGR. However, if the taxpayer cannot reasonably identify specific costs and expenses related to DPGR, the taxpayer has the option to then use a reasonable method to allocate costs and expenses between DPGR and all other income. These are some of the minor issues a large or small business may have to deal with in the first year of the deduction in order to comply with the rules under Section 199.

The accounting necessary to comply with the deduction is challenging, particularly for taxpayers who currently do not keep records conducive to tax reporting. Some of the accounting issues businesses have to consider are: 1) implementing accounting systems allocating gross receipts among qualifying property and non-qualifying property and services for purposes of identifying DPGR from other types of gross receipts. 2) Modifying existing accounting systems to allocate and apportion costs specifically identifiable to qualified production activities. 3) Modifying accounting systems in order to comply with the tracking of wages method for purposes of the wage limitation on the Section 199 deduction. 4) Setting-up separate profit centers in order to compute the appropriate gross profit stemming from goods manufactured, produced, grown, or extracted in the United States.

Small businesses may find the complying with Section 199 requirements very easy. They can merely add the appropriate accounts to their chart of accounts of the general ledger and modify their procedures for recording specific transactions relating to qualified production activities in their accounting systems. In contrast, larger businesses may have to substantially modify their accounting information systems and the way they record daily activity transactions in order to capture specific activities relating to qualified production. The objective for any business, small or large, is to figure out the amount of profit derived from qualified production activities that generate QPAI under the rules of IRC Section 199. Taxpayers should be looking out for opportunities for restructuring their contractual agreements and upgrading their accounting systems. All of the above may require a period of time, perhaps several years, of implementing and learning new accounting and tax software to capture QPAI and the related costs to that income. Taxpayers will now have to introduce new terms and conditions with customers, vendors, and other stakeholders as new contractual agreements are being drawn up or existing transactional agreements are being renewed. All in all, taxpayers must have a long-term perspective as long as they keep their books and records organized, to clearly identify income and costs relating to qualified production activities, utilizing the deduction will ultimately be beneficial.

The rules for the allocation of costs and expenses to QPAI are similar to the uniform capitalization ("UNICAP") rules under IRC Sections 263A and $861^{71}$. The amount determined to be COGS allocable to DPGR must be calculated using the principles under IRC Sections 263A, 471, and 472, respectively. However, with direct and indirect expenses, they have to be properly allocated using the method under IRC Section $861^{72}$.

A taxpayer's COGS allocable to DPGR have to be determined under the methods of accounting that the taxpayer uses to compute federal taxable income ${ }^{73}$. In the case of a sale, exchange, or other disposition of inventory, COGS is equal to beginning inventory plus purchases and production costs incurred during the taxable year, less

\footnotetext{
${ }^{70}$ See Notice $2005-14, \S 4.01$ regarding the meaning of "taxable income" for purposes of being eligible to claim the Section 199 deduction.

${ }^{71}$ Section 3.05(1) of Notice 2005-14.

${ }^{72}$ Section 3.05(3)(a) of Notice 2005-14.

${ }^{73}$ Regs. §1.199-4(b)(2); see former Prop. Regs. §1.199-4(b)(1).
} 
ending inventory ${ }^{74}$. If IRC Section $263 \mathrm{~A}$ requires a taxpayer to incorporate additional $\operatorname{costs}^{75}$ related to inventory, then those costs have to be factored in when calculating $\operatorname{COGS}^{76}$.

COGS apportioned to DPGR can also consist of inventory valuation adjustments, such as write downs under the lower of cost or market method ${ }^{77}$. Overall, a taxpayer has to allocate and apportion COGS in accordance with the rules under Section 199. A taxpayer can be eligible to use one of the simplified methods (the simplified deduction method and small business simplified overall method $^{78}$ ) to allocate COGS along with direct and indirect deductions to DPGR. With a sale, exchange, or other disposition of non-inventory property, such as theft, casualty, or abandonment, the COGS allocation rules state to include the property's adjusted basis. The COGS amount allocable to DPGR will not only include the inventory cost, but also the adjusted basis of qualifying production property ("QPP"), such as qualified films, or electricity, natural gas, and potable water utilities that will generate DPGR. Gross receipts attributable to the sale, lease, rental, license, exchange, or other disposition of the QPP will be included in the computation of gross income for a different taxable year ${ }^{79}$. However, pursuant to the de minimis exception, nonDPGR may be treated as DPGR, and then the COGS related to the non-DPGR have to be allocated appropriately to $\mathrm{DPGR}^{80}$. Likewise, accordingly to the final regulations of Treasury as well as to the de minimis exception rule, DPGR may be considered as non-DPGR, then the COGS related to the supposedly DPGR have to be allocated to nonDPGR $^{81}$.

All in all, other than a taxpayer that elects to use the small business simplified overall method for allocating and apportioning COGS, direct and indirect expenses to DPGR, pursuant to the final regulations of the Treasury, recognizes and reports gross receipts in a taxable year in which the payments were received (e.g., advance payments). If the taxpayer incurs COGS in a subsequent taxable year relating to such gross receipts that were included in gross income in a different taxable year, that were classified as DPGR, the taxpayer must allocate COGS in one of three ways. This has to be carried out regardless of whether the gross receipts were ultimately qualified as DPGR. The first way to allocate COGS would be to DPGR as long as the taxpayer can identify and match the related gross receipts as DPGR to the taxable year in which they were reported. The second way would be to allocate COGS to non-DPGR provided that the taxpayer identified and again matched the related gross receipts as non-DPGR to the taxable year in which they were reported. The third and final way would be the taxpayer recognizing such gross receipts under their method of accounting in a taxable year to which IRC Section 199 will not be applicable ${ }^{82}$.

The cost allocation method under IRC Section 861 consists of a two-step process. This method can be used by all taxpayers. Under the IRC Section 861 method, a taxpayer must allocate and apportion its deductions using the allocation and apportionment rules provided under the IRC Section 861 regulations under which section 199 is treated as an operative section described in Treasury Regulation Section 1.861-8(f) ${ }^{83}$. The method requires a taxpayer to first allocate expenses to the relevant class of gross income and then to apportion these expenses within the class of gross income between DPGR and non-DPGR items. IRC Section 861 has special rules for the allocation and apportionment of particular types of expenses related to gross income, which include the following: 1) interest ${ }^{84}, 2$ ) state income

\footnotetext{
${ }^{74}$ Regs. §1.199-4(b)(1); former Prop. Regs. §1.199-4(b)(1).

${ }^{75}$ Other than interest, additional $\$ 263 \mathrm{~A}$ costs are expenditures that may or may not have to be capitalized. This depends on whether 1) the taxpayer's method of accounting being used or 2) how long has the taxpayer been in existence prior to the effective date of IRC Section 263A; Regs. §1.263A-1(d).

${ }^{76}$ Regs. §1.199-4(b)(1); former Prop. Regs. §1.199-4(b)(1).

${ }^{77} I d$.

${ }^{78}$ Regs. $\$ 1.199-4(b)(1)$; former Prop. Regs. $\$ 1.199-4(b)(1)$; IRC Section 199(c)(2), as amended retroactively under the Gulf Opportunity ("GO”) Zone Act of 2005, P.L. 109-135, §403(a)(4).

${ }^{79}$ For case in point, any advance payments associated to DPGR may be included in gross receipts under Regs. §1.451-5(b)(1)(i), but may not be properly matched to the associated COGS figure since the payments were received and recognized in a different taxable year. Regs. §1.199-4(b)(1); former Prop. Regs. §1.199-4(b)(1).

${ }^{80}$ Regs. §1.199-4(b)(1); see former Prop. Regs. §1.199-4(b)(1).

${ }^{81}$ Regs. $\$ 1.199-4(\mathrm{~b})(1)$.

${ }^{82}$ Regs. \$1.199-4(b)(2)(ii).

${ }^{83}$ Regs. §1.199-4(d)(1); see former Prop. Regs. §1.199-4(d)(1).

${ }^{84}$ Regs. §1.861-9T(a) and Regs. §1.199-4(c); see former Prop. Regs. §1.199-4(c).
} 
$\operatorname{taxes}^{85}, 3$ ) charitable contributions ${ }^{86}$, and 4) research and development ("R\&D") ${ }^{87}$. Overall, amounts allocated to any specific activities can vary substantially, unless proper care and level of analysis is carried out in support of particular allocations and apportionments. An extensive analysis of sales, general and administrative expenses ("SG\&A") may result in an increase in a taxpayer's QPAI resulting in a benefit greatly from the Section 199 deduction. Communicating to the client is the first and foremost important step in order to complete such an analysis since the client has to provide the needed information. They may accomplish this task through the use of templates to assist in the computations and information gathering. Of course, such a SG\&A analysis alone will not necessarily provide an entire cost allocation solution. In order, to provide a completed solution analysis, SG\&A and other types of expenses will have to be combined with the specific rules contained in IRC Section 861.

Notice 2005-14 and the final regulations of the Treasury permit taxpayers to allocate and apportion deductions in one of two ways under the safe harbor provisions. The first type is the simplified deduction method. The only taxpayers allowed to use this method, for its direct and indirect costs, are those with average annual gross receipts ${ }^{88}$ of $\$ 100$ million or less ( $\$ 25$ million or less for taxable years beginning before June 1,2006 ) or, at the end of the taxable year, total assets ${ }^{89}$ of $\$ 10$ million or less ${ }^{90}$. These deductions, which do not include COGS and the NOL deduction, are then ratably allocated and apportioned between DPGR and non-DPGR based on the percentage of gross receipts that are DPGR ${ }^{91}$. The final method that a taxpayer can use is the small business simplified overall method. Eligible taxpayers are those that 1) have both average annual gross receipts of $\$ 5,000,000$ or less (the same for taxable years beginning before June 1, 2006), and total COGS and deductions (which do not include any NOL deductions) for the current taxable year of $\$ 5,000,000$ or less, ${ }^{92}$ ) is engaged in the trade or business of farming and is not required to use the accrual method of accounting as provided under IRC Section 447, or 3) certain taxpayers with average annual gross receipts of $\$ 10$ million or less, which are not forbidden from using the cash method of accounting under IRC Section 448, including C corporations, individuals, partnerships, or S corporations ${ }^{93}$. Electing to use this method of allocating total costs for the current taxable year apportions COGS as well as deductions between DPGR and nonDPGR (e.g., all other income) based on the amounts of relative gross receipts ${ }^{94}$. The amount of a taxpayer's COGS and deductions for the taxable year are apportioned to DPGR based on the percentage that the amount of a taxpayer's DPGR yields to the taxpayer's total gross receipts ${ }^{95}$.

\section{DOMESTIC PRODUCTION GROSS RECEIPTS: CONSTRUCTION PERFORMED IN THE UNITED STATES AND LAND DEVELOPERS}

A taxpayer engaged in conducting an active construction trade or business may be entitled to the domestic production activities deduction. In order to qualify for the deduction, construction activities must be performed for projects in the U.S. in an ordinary course of a trade or business by the taxpayer. The proceeds from the sale, exchange, or other disposition of real property, totaling gross receipts derived from construction of real property by the taxpayer in the United States, would be includable in DPGR ${ }^{96}$. However, the property qualifying for DPGR does not need to be sold immediately after the construction has been completed, nor must the construction project or job be complete. DPGR derived from the construction of real property also includes compensation for the performance of construction

\footnotetext{
${ }^{85}$ Regs. $\$ 1.861-8(\mathrm{e})(6)$.

${ }^{86}$ Section 4.05(3)(c)(ii) of Notice 2005-14 and Regs. $\$ 1.199-4(d)(2)$; former Prop. Regs. §1.199-4(d)(2).

${ }^{87}$ Regs. §1.861-17(a)(1) and Regs. §1.199-4(d)(3).

${ }^{88}$ Defined under Regs. $\$ 1.199-4(\mathrm{~g})$; see former Prop. Regs. $\$ 1.199-4(\mathrm{~g})$.

${ }^{89}$ Defined under Regs. \$1.199-4(e)(3); see former Prop. Regs. \$1.199-4(h).

${ }^{90}$ Regs. §1.199-4(e)(1), (e)(2); former Prop. Regs. §1.199-4(e)(1).

${ }^{91}$ Section 4.05(3)(d) of Notice 2005-14; Regs. \$1.199-4(e)(1); see former Prop. Regs. §1.199-4(e)(1).

${ }_{92}$ Regs. §1.199-4(f)(1), §1.199-4(f)(3)(i); see former Prop. Regs. §1.199-4(f)(1).

${ }^{93}$ Regs. §1.199-4(f)(2); former Prop. Regs. §1.199-4(f)(2), (i)(1). The types of taxpayers that may eligible to use the small business simplified overall method is any taxpayer that is qualified to employ the cash method under Rev. Proc. 2002-28, 2002-1 C.B. 815. Section 4.05(4)(b) of Notice 2005-14.

${ }^{94}$ Regs. §1.199-4(f)(1); former Prop. Regs. §1.199-4(f)(1) and Section 4.05(4)(a) of Notice 2005-14. However, as part of the land safe harbor provision under Regs. $§ 1.199-3(\mathrm{~m})(6)(\mathrm{iv})$, any gross receipts allocated to land are not to be included in the overall total of gross receipts.

${ }_{95}^{95}$ Regs. §1.199-4(f)(1); former Prop. Regs. §1.199-4(f)(1) and Section 4.05(4)(a) of Notice 2005-14.

${ }^{96}$ IRC Section 199(c)(4)(A)(ii), as amended retroactively by the Gulf Opportunity Zone Act of 2005, P.L. 109-135, §403(a)(5).
} 
services by the taxpayer in the United States ${ }^{97}$. In the end, the determination of what constitutes construction services is made on a case-by-case basis after all of the facts and circumstances.

The meaning of construction activities entails erection or substantial renovation of real property, which may include residential and commercial buildings along with their structural components. Real property may also essentially include permanent structures other than tangible personal property in the nature of machinery, land improvements, oil and gas wells, as well as infrastructure ${ }^{98}$. Substantial renovation of real property involves renovation of major components or permanent structures, which increases the value, significantly extends the useful life, or adapts a new or different use of the property ${ }^{99}$. At the time a taxpayer constructed the real property in the U.S., the taxpayer must be actively engaged in the trade or business of construction; however, not necessarily the taxpayer's primary trade or business. For a taxpayer to be considered as engaged in the active conduct of a construction trade or business, each company must be tested on an entity-by-entity basis to determine whether an entity falls within the North American Industry Classification System ("NAICS") $\operatorname{codes}^{100}$. In order for gross receipts derived from the sale of a building to qualify as DPGR, the taxpayer must solely perform the construction activities ${ }^{101}$. However, there can be an occasion where there might be more than one taxpayer deriving gross receipts from the same construction activity or project.

\section{Example 1}

Taxpayer hires a general contractor ("G") to perform substantial renovation of a commercial building. G goes out and hires a subcontractor contractor ("S") to perform plumbing and heating services as part of the substantial renovation. The amounts paid to $\mathrm{G}$ and $\mathrm{S}$ will be classified as DPGR. On the other hand, since Taxpayer did not perform any construction activities relating to the commercial building, the proceeds from the sale of the building will not be qualified as DPGR to Taxpayer.

Any gross receipts derived from the sale of tangible personal property manufactured by the taxpayer or the lease or rental of real property will not be eligible as DPGR, and thus not includable in DPGR. Furthermore, any tangible personal property being sold as part of a finished construction project would not be considered as real property. This would include such items as appliances, equipment, or furniture $\&$ fixtures. If less than five percent (" $5 \%$ ") of the total gross receipts earned by the taxpayer is derived from construction activities of real property in the United States, then a safe harbor rule applies. This entails that any gross receipts derived by the taxpayer from nonconstruction activities, such as the sale of tangible personal property or land, would be considered as gross receipts derived from construction activities of real property in the U.S., and thus included and qualifying as DPGR ${ }^{102}$.Any tangential services, such as hauling trash and debris, and delivering materials on and off the construction site, even if the tangential services are essential for construction, are not includable in determining DPGR. However, whenever a taxpayer performs both the construction to the project or job, as well as provides tangential services in connection with the construction project or job, the taxpayer is allowed to include the gross receipts derived from the tangential services in DPGR. A taxpayer engaged in such activities relating to construction that perform land improvements, such as, grading and landscaping and painting in connection with other activities, whether or not performed by the same taxpayer, must make a reasonable determination of whether the activities performed relates to the erection or substantial renovation of real property. Activities relating to oil drilling and mining also qualify as construction

\footnotetext{
${ }^{97}$ Regs. $\$ 1.199-3(\mathrm{~m})(6)(\mathrm{i})$.

${ }^{98}$ Regs. \$1.199-3(m)(4). The meaning of infrastructure in this context would consist of roads, power lines, water systems, railroad spurs, communications facilities, sewers, sidewalks, cable, wiring, and permanent platforms of oil and gas.

${ }^{99}$ Regs. $\$ 1.199-3(\mathrm{~m})(4)$.

${ }^{100}$ Prop. Regs. §1.199-3(1)(1)(i). NAICS codes may be found at http://www.census.gov/epcd/www/naics.html. In order for a trade or business to be considered in the activity of construction, the activity is identified as a two-digit NAICS code of 23 or any other NAICS code relating to the activity of construction of real property.

${ }^{101}$ Regs. $\$ 1.199-3(\mathrm{~m})(1)(\mathrm{i})$.

102 Regs. $\$ 1.199-3(\mathrm{~m})(1)(\mathrm{iii})(\mathrm{A})$. This safe harbor rule replaces the existing rule stated in Notice 2005-14, 2005-7 I.R.B. 498, $\S 4.04(11)(a)$. The regulation goes onto state that if more than ninety-five percent ("95\%") of the total revenue earned from a construction project are derived from real property, as explained under $\$ 1.263 \mathrm{~A}-8(\mathrm{c})$ of the Treasury Regulations, subsequently the total income received from the project is all considered to be categorized as DPGR.
} 
activities under Section 199. Furthermore, where a taxpayer is allowed and able to deduct intangible drilling and development costs and expenditures for a mine or natural deposit, the costs also qualify as construction activities ${ }^{103}$.A taxpayer in the business of leasing, licensing, or renting equipment and machinery, such as computers, generators, trucks, or bulldozers to contractors for use in the construction of the real property, is not considered to be in construction activity. Any gross receipts derived from such activities of renting or leasing equipment and machinery to contractors for use in the construction of real property are non-DPGR, if the rental companies do not manufacture the equipment or machinery. Any gross receipts from the lease or rental of real property constructed by the taxpayer are not considered DPGR derived from the construction of real property under Section 199. In addition, gross receipts due to the sale or other disposition of land, which also encompasses zoning, planning, entitlement costs, and other costs capitalized to the land, such as the demolition of structures, are not DPGR derived from the construction of real property ${ }^{104}$. Lastly, any activities that relate to and meet the characterization of engineering and architectural services are not included as construction activities ${ }^{105}$.

Gross receipts from any warranties provided in connection with the construction of real property in the normal course of a taxpayer's construction trade or business, is classified as DPGR derived from the construction of real property. The charge for the construction warranty will be included in DPGR so long as the price for the construction project and the construction warranty is neither separately offered by the taxpayer nor separately bargained for with the customer (e.g., the customer cannot purchase the constructed real property without the construction warranty) ${ }^{106}$.

Any gross receipts attributable to land, which might be in connection with qualifying construction activities, must identify and value such gross receipts in order to specifically exclude only gross receipts attributable to land from domestic production gross receipts for purposes of the domestic production activities deduction. The proposed Treasury Regulations provide a safe harbor under which a taxpayer may allocate gross receipts between the proceeds from the disposition of real property constructed by the taxpayer and the gross receipts attributable to the disposition of land by reducing its costs allocable to DPGR by costs of the land and any other costs capitalized to the land. Collectively, such land costs might include zoning, planning, entitlement costs, and other costs capitalized to the land such as the demolition of structures ${ }^{107}$ and land costs in any common improvements ${ }^{108}$ and by reducing its DPGR by those land costs plus a specified percentage. The percentage is based on the number of years between the date the taxpayer acquires the land, including the date the taxpayer enters into the first option to acquire all or a portion of the land, and ends on the date the taxpayer sells each item of real property on the land. The percentage is $5 \%$ for years 0 through 5;10\% for years 6 through 10; and 15\% for years 11 through 15. Land that a taxpayer holds for 16 or more years is not eligible for this safe harbor, and the taxpayer must allocate gross receipts between land and qualifying real property. For example, if a taxpayer acquires land in 2001 and constructs houses that it sells in 2005, 2008, and 2012, the houses sold in 2005 are subject to the 5\% reduction; the houses sold in 2008 are subject to the $10 \%$ reduction; and the houses sold in 2012 are subject to the $15 \%$ reduction ${ }^{109}$.

\section{DOMESTIC PRODUCTION GROSS RECEIPTS: ARCHITECTURAL AND ENGINEERING SERVICES}

The U.S. production activities deduction gives rise to engineering or architectural services performed by a taxpayer that is engaged in an active conduct of an engineering or architectural services trade or business ${ }^{110}$. In order for the taxpayer to qualify for the deduction, such services must be performed in the United States for the construction of real property in the United States ${ }^{111}$. Any gross receipts derived from engineering or architectural services performed in the United States for the construction of real property in the United States are then allowed to be

\footnotetext{
${ }^{103}$ Regs. $\$ 1.199-3(\mathrm{~m})(2)(\mathrm{v})$.

${ }^{104}$ Regs. $\$ 1.199-3(\mathrm{~m})(6)(\mathrm{ii})$

105 Regs. $\$ 1.199-3(\mathrm{~m})(2)$.

${ }^{106}$ Regs. $\$ 1.199-3(\mathrm{~m})(6)(\mathrm{ii})$. Also, see Regs. $\$ 1.199-3(\mathrm{~m})(6)(\mathrm{v})$ for examples.

${ }^{107}$ IRC Section $\$ 280 B$.

${ }^{108}$ Rev. Proc. 92-29, 1992-1 C.B. 748, \$2.01.

${ }^{109}$ Regs. $\$ 1.199-3(\mathrm{~m})(6)(\mathrm{iv})(\mathrm{A})$. Also, see Regs. $\$ 1.199-3(\mathrm{~m})(6)(\mathrm{v})$ for examples.

${ }^{110}$ IRC Section 199(c)(4)(A)(iii), as amended retroactively by the Gulf Opportunity Zone Act of 2005 ("GO Zone”), P.L. 109-135, $\S 403(\mathrm{a})(5)$.

${ }^{111}$ IRC Section 199(c)(4)(A)(iii) and Regs. §1.199-3(n)(1).
} 
included in DPGR. The determination of what constitutes an item for purposes of architectural or engineering services is decided on a case-by-case basis, taking into account all of the facts and circumstances. All engineering or architectural services have to be related to real property and must be performed in the United States ${ }^{12}$.

Under the proposed regulations, to be eligible to claim the deduction from providing engineering and architectural services, the regulations require that at the time the taxpayer performed such services, the taxpayer is actively engaged in an engineering or architectural services trade or business ${ }^{113}$. Such engineering or architectural services may not necessary be the taxpayer's primary or only trade or business. A taxpayer must be engaged in a regular and ongoing trade or business that is considered engineering or architectural services for purposes of the North American Industry Classification System ("NAICS") ${ }^{114}$. Determining whether an entity's principal business activity falls under the appropriate NAICS code is made on an entity-by-entity basis.

If a planned construction project or job is not undertaken, completed, or falls through, it does not disqualify such gross receipts to be excluded from DPGR ${ }^{115}$. Gross receipts derived from rendering engineering or architectural feasibility studies or services for a failed construction project or job in the United States will still be considered DPGR. Such engineering services, requiring engineering education, training, and experience and the application of special knowledge of the mathematical, physical, or engineering sciences to those professional services, would include any of the following professional services: 1) consultation, 2) investigation, 3) evaluation, 4) planning, 5) design, or 6) responsible supervision of construction for the purpose of assuring compliance with plans, specifications, and $\operatorname{design}^{116}$.

Architectural services in connection with any construction project include the offering or furnishing of any professional services such as consultation, planning, aesthetic and structural design, drawings and specifications, or responsible supervision of construction, which is the purpose of assuring compliance with plans, specifications, and design or erection, in connection with any construction project ${ }^{117}$. A safe harbor rule is applicable where less than five percent ("5\%") of the total gross receipts is derived from rendering engineering or architectural services that are either performed outside the United States or related to property other than real property to be treated as qualified DPGR ${ }^{118}$.

\section{DOMESTIC PRODUCTION GROSS RECEIPTS: QUALIFIED FILMS}

A film that is created, manufactured, or produced in the U.S. is considered qualified production activities under Section 199 so long as the film is either a motion picture, video tape, or a live or delayed television programming. Thus, DPGR includes the gross receipts of the taxpayer which are derived from any lease, rental, license, sale, exchange, or other disposition of any qualified film produced by the taxpayer. The qualifying film has to be either the master copy or another copy of the film. The only way a copy of the qualifying film would be acceptable of meeting the requirement under Section 199 would be if the taxpayer creates and produces copies. Certain types of films and other items relating to the production of a qualified film are not considered as qualified films for purposes of taking the domestic production activities deduction under Section 199. This includes tangible property, such as videocassettes and DVDs used to hold the film; films, videotapes, DVDs, or other matter that depicts actual sexually explicit conduct, such as pornographic videos ${ }^{119}$; ticket sales for viewing qualified films; screenplays or other writings even if such material developed into a qualified film; sales of tangible personal property that is film-themed merchandise; and a license of the right to use the film characters.

Compensation paid to personnel relating to the production of a qualified film has to be allocated to activities,

\footnotetext{
112 Originally under Notice 2005-14, the taxpayer providing such services had to substantiate that the services related to a construction project or job within the United States. However, the proposed regulations eliminated this additional requirement.

${ }^{113}$ Regs. $\$ 1.199-3(\mathrm{n})(1)$.

${ }^{114} I d$.

${ }^{115} \mathrm{Id}$.

${ }^{116}$ Regs. $\$ 1.199-3(\mathrm{n})(2)$.

${ }^{117}$ Regs. $\$ 1.199-3(n)(3)$.

${ }^{118}$ Regs. §1.199-3(n)(4).

${ }^{119}$ Regs. §1.199-3(k)(6); IRC Section 199(c)(6) (defined by 18 USC §2257).
} 
which are directly involved and ancillary to the film production. The only compensation paid to personnel that qualifies toward the 50\% test are those directly involved in the film production and at least fifty percent ("50\%") or more of the services were performed in the United States by actors and production personnel, which includes directors and producers ${ }^{120}$. Such compensation paid to qualifying personnel in the production of the film, counts towards the fifty percent ("50\%") test. Qualifying compensation would include such production personnel as writers, choreographers, composers, casting agents, camera operators, set designers, lighting technicians, and make-up artists. Individuals whose activities are ancillary to the film production, such as advertisers, promoters, distributors, studio administrators and managers, studio security personnel, personal assistants to actors, and activities relating to fixing the film on tangible personal property, would not qualify as production personnel ${ }^{121}$.

The amount of compensation paid to individuals for services relating to the production of a qualified film includes W-2 wages as well as independent contractors, whose activities are, again, directly involved to the film production. In addition to $\mathrm{W}-2$ wages and independent contractors, compensation in the form of residuals and participations, as defined under Section $167(\mathrm{~g})(7)(\mathrm{B})$ of the IRC, relating to the production, is also included in total compensation $^{122}$. Compensation for services includes all compensation where such amounts must be capitalized under the uniform capitalization rules as prescribed under Section 263A of the Internal Revenue Code. When allocating the appropriate amount of compensation in determining whether the fifty percent ("50\%") test has been met, the taxpayer is allowed to use any reasonable method. The taxpayer's use of such method of allocating compensation is considered to be reasonable when the method is used consistently by the taxpayer ${ }^{123}$.

The taxpayer may treat the tangible personal property, such as DVDs, with the affixed film that the taxpayer licenses from the producer of the film, regardless of whether the film is a qualified film, as QPP as long as the taxpayer manufactured, produced, grown, or extracted the property in whole or in significant part in the U.S. For each item sold, the cost associated with the licensing of the film from its producer would be taken into consideration when figuring COGS $^{124}$. If the qualified film is affixed to a tangible medium, where the taxpayer may or may not have manufactured, produced, grown, or extracted the medium in whole or in significant part within the U.S., such as a DVD, the taxpayer can treat the tangible personal property as part of the qualified film when deriving at DPGR ${ }^{125}$. However, if the film affixed to the tangible medium is not considered to be a qualified film, then for each item sold, any gross receipts earned, has to be allocable between the nonqualified film and the tangible personal property when calculating DPGR ${ }^{126}$.

Any gross receipts derived from presenting a qualified film over the television is not considered to be DPGR. In addition to television showings, gross receipts resulting from ticket sales, as well as the sale of a script or screenplay, which might be developed into a qualified film, are not DPGR. Gross receipts earned from the sale of film-themed merchandise are categorized as sales of tangible personal property and not derived from a qualified film. Furthermore, a license of the right to use the film characters is not considered as revenue generated from a qualified film $^{127}$.

\footnotetext{
${ }^{120}$ IRC Section 199(c)(6); Regs. §1.199-3(k)(1).

${ }^{121}$ Regs. §1.199-3(k)(1).

${ }^{122}$ Regs. $\$ 1.199-3(k)(4) ;$ H.R. Conf. Rep. No. 755, $108^{\text {th }}$ Cong., $2^{\text {nd }}$ Sess. 260 (2004).

${ }^{123}$ Former Prop. Regs. $\$ 1.199-3(\mathrm{j})(6)$.

${ }^{124}$ Former Prop. Regs. $\$ 1.199-3(j)(2)(i)$. To establish whether gross receipts earned from the lease, rental, license, sale, exchange, or other disposition of the tangible personal property with the affixed film are considered to be DPGR is determined under Prop. Regs. $\$ 1.199-3(d),(e)$, and (f).

${ }^{125}$ Regs. $\$ 1.199-3(\mathrm{k})(2)(\mathrm{ii})$.

${ }^{126}$ Regs. $\$ 1.199-3(k)(2)(i i)$. Former Prop. Regs. §1.199-3(j)(2)(ii)(B). To establish whether gross receipts earned from the lease, rental, license, sale, exchange, or other disposition of the tangible personal property with the affixed nonqualified film, and only allocable to the tangible medium, are considered being DPGR when tested under the rules of Prop. Regs. §1.199-3(d), (e), and (f).

${ }^{127}$ Regs. §1.199-3(k)(3).
} 


\section{DOMESTIC PRODUCTION GROSS RECEIPTS: ELECTRICITY, NATURAL GAS, AND POTABLE WATER}

The production of electricity, natural gas, or potable water in the United States qualifies for the deduction ${ }^{128}$. The gross receipts derived from any lease, rental, license, sale, exchange, or other dispositions of these natural resources are includable in DPGR ${ }^{129}$. Any gross receipts received from the storage, transmission, or distribution of these items is not includable as DPGR ${ }^{130}$. However, if the taxpayer produces, as well as transmits or distributes electricity, natural gas, and potable water in the United States, the taxpayer can still qualify for the deduction; but, in doing so, the taxpayer or the integrated producer has to then allocate gross receipts between qualifying production activities, for purposes of including such receipts in DPGR, and non-qualifying transmission and distribution activities, in order to exclude such receipts from DPGR ${ }^{131}$. A safe harbor rule is applicable when less than five percent (" $5 \%$ ") of a taxpayer's gross receipts is attributable to the sale, exchange, or other disposition of utility transmission or distribution activities. As a result, the gross receipts derived from such activities have to be then included as DPGR $^{132}$.

The production of natural gas generally consists of only natural gas extracted from a natural deposit. This production involves extracting natural gas from the ground and processing the gas into pipeline quality gas ${ }^{133}$. The extraction of methane gas from a landfill is not considered to be extracted from a natural deposit. Gross receipts derived from the production of potable water involve the acquisition, collection, and storage of raw or untreated water, transportation, and treatment of raw water to a water treatment facility. Such receipts are then included in DPGR. With respect to the production of bottled water in the United States, this type of production is classified as tangible personal property, instead of being considered as production of potable water. No special allocation of gross receipts is needed between the production of bottled water (e.g., tangible personal property) and production of potable water $^{134}$.

\section{DOMESTIC PRODUCTION ACTIVITIES DEDUCTION AFFECTING PASS-THROUGH ENTITIES}

The manufacturer's deduction is available to pass-through entities, such as partnerships, S corporations, estates, and trusts ${ }^{135}$. The Section 199 deduction is applied and determined at the partner, shareholder, or owner level ${ }^{136}$. It is up to all the individual partners, shareholders, or owners to calculate their own appropriate share of the manufacturer's deduction in proportion to their distributive share of the pass-through entity's items attributable to the qualifying production activities according to the economic arrangement of the owners. Further, the activity attribution rules are not applicable to pass-through entities in Section $199^{137}$. Attribution rules are qualifying production property transferred between the pass-through entity and the partner, shareholder, or owner. When these types of transactions occur, the partner, shareholder or owner of a pass-through entity, and the pass-through entity itself, is not considered as directly conducting qualified production activities. If a pass-through entity distributes, sells, exchanges, leases, rents, licenses, or otherwise disposes of qualified production property that was manufactured, produced, grown, or extracted within the U.S. to a partner, shareholder, or owner; the partner's, shareholder's, or owner's gross receipts from the latter lease, rental, license, sale, exchange, or other disposition of the property, is not treated as DPGR. Similarly, if a pass-through entity purchases qualifying production property that was manufactured, produced, grown, or extracted within the U.S. by a partner, shareholder, or owner, the pass-through entity's gross receipts from the latter

\footnotetext{
${ }^{128}$ IRC Section 199(c)(4)(A)(i)(III).

${ }^{129}$ Regs. $\$ 1.199-3(1)(1)$.

${ }^{130}$ Regs. \$1.199-3(1)(4).

${ }^{131}$ Regs. §1.199-3(1)(1).

${ }^{132}$ Regs. $\$ 1.199-3(1)(4)($ iv)(A).

${ }^{133}$ Regs. §1.199-3(1)(2).

${ }^{134}$ Regs. \$1.199-3(1)(3).

135 IRC Section 199(d)(1)

${ }^{136}$ IRC Section 199(d)(1)(A)(i); Regs. §1.199-9.

${ }^{137}$ Notice 2005-14, $\$ 4.07$. Within that section of the Notice, two (2) exceptions apply for agricultural organizations as well as oil and gas partnerships.
} 
lease, rental, license, sale, exchange, or other disposition of the property is not treated as DPGR ${ }^{138}$. This rule applies to all partnerships even if the partnership elected out of subchapter $\mathrm{K}$ status.

The W-2 wage limitation on the amount of the Section 199 deduction also pertains to pass-through entities. The determination of partners', shareholders', or owners' portion of W-2 wages is first required at the pass-through entity level and then ultimately the W-2 wage limitation is affected at the partner, shareholder, or owner level ${ }^{139}$. When the partners, shareholders, or owners are allocated items attributable to qualified production activities from a pass-through entity, for purposes of applying the W-2 wages limitation, they are allocated an amount equal to the lesser of: a) their allocable portion of such W-2 wages; or b) two times the Section 199 deduction applicable percentage of the qualified productions activities income ("QPAI"). The applicable percentages are: three percent ("3 \%") for tax years beginning in 2005 and 2006, six percent ("6\%") for tax years beginning in 2007, 2008, and 2009, and nine percent ("9 \%") for tax years beginning in 2010 and thereafter ${ }^{140}$.

In general, Section 199 is effective for taxable years starting on or after January 1, 2005 to pass-through entities $^{141}$. The manufacturer's deduction will not pertain to pass-through entities with taxable years beginning before 2005. For instance, if a pass-through entity has a fiscal year beginning on July 1, 2004 and ending on June 30, 2005, under the rules of Section 199, the deduction will not be available to the pass-through entity until its taxable year beginning July 1, 2005. Its partners, shareholders, or owners of the pass-through entity have calendar years taxable ending on December 31, 2005. As a result, the partners, shareholders, or owners of the pass-through entity will not be able to compute and report their respective Section 199 deductions from their distributive or pro rata share of items attributable to the qualified production activities of the pass-through entity until taxable year ending December 31, $2006^{142}$.

\section{PASS-THROUGH ENTITIES: PARTNERSHIPS}

The manufacturer's deduction is computed separately by each partner since the Section 199 deduction is applied and determined at the partner level. The partnership allocates to each partner the entity's items of income, gain, loss, and deduction ${ }^{143}$. Partnerships allocate cost of goods sold and gross receipts to the partners where such items have been allocated to or included in income, respectively ${ }^{144}$. This allocation of items would still take effect even if cost of goods sold and other deductions and losses exceed DPRG for any one partner. Moreover, a partnership can also have any special allocation of the Section 199 deduction. The partnership can specifically allocate items of income, gain, loss, or deduction attributable to the partnership's qualified production activities to any of its partners so long as such allocations pass the substantial economic effect safe harbor rules ${ }^{145}$.

In order for the partner to calculate an allowable and reasonable deduction under Section 199 for the taxable year, the partner has to use the aggregate approach. Under this approach, the partners separately take into account his or her own distributive share of DPGR, expenses, and W-2 wages attributable to the partnership's qualified production activities whether or not there is taxable income from the partnership. The partner then combines these items allocable from the pass-through entity's qualified production activities, with items from other qualified production activities (e.g., items that a partner might incur outside the partnership whether or not directly involved in the operations of the business) in order to allocate and apportion deductions to DPRG and calculating QPAI.

In spite of whether the partnership has taxable income, the partners have to take into consideration his or her distributive share of expenses pertaining to the partnership's qualified production activities. To the extent there is a

\footnotetext{
${ }^{138}$ Regs. $\$ 1.199-9(\mathrm{~h})$.

${ }^{139}$ IRC Section 199(d)(1)(B)

${ }^{140}$ IRC Section 199(a)(2), (d)(1)(B)

${ }^{141}$ P.L. 108-357, IRC Section $\$ 102(\mathrm{e})$.

${ }^{142}$ Notice 2005-14, 2005-7 I.R.B. 498, §4.06(3).

${ }^{143}$ IRC Sections $§ 702$ and $\$ 704$.

${ }^{144} \mathrm{Id}$.

${ }^{145}$ IRC Section §704(b).
} 
deficient basis, employing the passive activity rules ${ }^{146}$ or at-risk rules ${ }^{147}$, disallow losses or deductions, a proportionate share of the losses or deductions reflecting expenses allocable from the partnership's qualified production activities will also be suspended. In the event any disallowed losses or deductions are allowed to be used, the partner takes into account a proportionate share of the suspended Section 199 QPAD or expenses reflected in those losses or deductions in determining QPAI in such taxable year ${ }^{148}$. Lastly, the Section 199 deduction can be claimed whether or not a partner of a partnership is directly involved in the production activities of the business ${ }^{149}$.

\section{PASS-THROUGH ENTITIES: S CORPORATIONS}

The manufacturer's deduction is computed separately by each shareholder since the Section 199 deduction is applied and determined at the shareholder level. The $\mathrm{S}$ corporation allocates to each shareholder on a pro rata basis the entity's items of income, gain, loss, and deduction ${ }^{150}$. In addition, $\mathrm{S}$ corporations allocate on a pro rata basis, cost of goods sold and gross receipts to the shareholders where such items have been allocated to or included in income, respectively ${ }^{151}$. This allocation of items attributable to the $\mathrm{S}$ corporation's qualified production activities would still take effect even if cost of goods sold and other deductions and losses exceed DPGR for any one shareholder. In order for the shareholder to come up with an allowable and reasonable deduction under Section 199 for the taxable year, the shareholder has to use the aggregate approach. Under this approach, the shareholders separately take into account his or her own pro rata share of DPGR, expenses, and W-2 wages attributable to the corporation's qualified production activities whether or not there is taxable income from the corporation. The shareholder then combines his or her pro rata share of such items allocable from the pass-through entity's qualified production activities with items from other qualified production activities (e.g., items that a shareholder might incur outside the $\mathrm{S}$ corporation whether or not directly involved in the operations of the business) in order to allocate and apportion deductions to DPRG and calculating QPAI.

Again, whether or not the shareholder has taxable income, the shareholders have to take into consideration his or her pro rata share of expenses pertaining to the S corporation's qualified production activities. To the extent there is a deficient basis, employing the passive activity rules ${ }^{152}$ or at-risk rules ${ }^{153}$, disallow losses or deductions, a proportionate share of the losses or deductions reflecting expenses allocable from the S corporation's qualified production activities will also be suspended. In the event any of the disallowed losses or deductions is allowed to be used, the shareholder takes into account a proportionate share of the suspended Section 199 QPAD or expenses reflected in those losses or deductions in determining QPAI in such taxable year ${ }^{154}$. Lastly, the Section 199 deduction can be claimed whether or not a shareholder of an S corporation is directly involved in the production activities of the business $^{155}$.

\section{TRUSTS AND ESTATES}

An owner of a grantor trust calculates its QPAI, based on the person's percentage of ownership in the trust, as if that QPAI had been generated by activities completed solely by the owner ${ }^{156}$. To determine the Section 199 deduction for a non-grantor trust or estate, the QPAI must be calculated by allocating expenses, losses, and deductions directly attributable to DPGR ${ }^{157}$. The simplified deduction method must be used with respect to allocating other

\footnotetext{
${ }^{146}$ IRC Section 469.

${ }^{147}$ IRC Section 465.

${ }^{148}$ Regs. $\$ 1.199-9$ (b)(2) \& Notice 2005-14, §4.06(1).

${ }^{149}$ Regs. $\$ 1.199-9$.

${ }^{150}$ IRC Sections $§ 1366$.

${ }^{151} I d$.

${ }^{152}$ IRC Section 469.

${ }^{153}$ IRC Section 465.

${ }^{154}$ Regs. $\$ 1.199-9$ (c)(2)(ii) \& Notice 2005-14, §4.06(1).

${ }^{155}$ Regs. \$1.199-9.

${ }^{156}$ Regs. \$1.199-9(d).

${ }^{157}$ IRC Section 199(d)(5); Regs. \$1.652(b)-3.
} 
expenses, losses, and deductions to DPGR ${ }^{158}$. However, if the trust or estate is not eligible to use the simplified deduction method, the only alternative for the trust or estate is the Section 861 method with respect to allocating other expenses, losses, and deductions to DPGR. When a trust or estate is computing its QPAI for the taxable year, the trust or estate is not permitted to use the small business simplified overall method.

The QPAI of the trust or estate is distributed among the beneficiaries and to the trust or estate based on the proportionate share of the trust's or estate's net income for the taxable year that is distributed or required to be distributed to the beneficiaries or is retained by the trust or estate. Any QPAI is allocated entirely to the trust or estate when the trust or estate has no net income for the taxable year. Conversely, QPAI can be a negative amount if cost of goods sold and expenses, losses, and deductions allocated and appropriated to DPGR exceed the trust's or estate's DPGR. The Section 199 deduction is available to a trust or estate when computing its taxable income for the year only to the extent that QPAI and W-2 wages are allocated to the trust or estate. When beneficiaries of a trust or estate are computing their taxable income for the year, they are permitted to take the Section 199 deduction, subject to the wage limitation, based on their proportionate share of QPAI and W-2 wages distributed from the trust or estate, which are then combined with QPAI and W-2 wages from other sources ${ }^{159}$.

\section{CONCLUSION}

Congress recognized manufacturers are an important segment of the U.S. economy. Manufacturers have been facing a considerable amount of pressure and challenges during the nation's recent economic slowdown. As a result, legislation crafted a deduction for the first time ever, to U.S. based manufactures and producers to assist, attract, and retain economically vibrant industries. This will create healthy jobs for U.S. workers; but more importantly, contribute financial growth overall to the U.S. economy.

Legislators repealed the export tax benefit since it was deemed to be inconsistent with the obligations of the United States under many international trade agreements. Accordingly, legislators replaced this benefit with a tax relief specifically designed to be economically equivalent to a three-percentage point reduction in the corporate income tax rate, which is currently thirty five percent. Congress was also concerned about the adverse competitive impact of foreign subsidies on U.S. manufactures and producers. Foreign trading partners of the U.S. retaining subsidies for domestic manufacturing, as well as concerns about exporting those manufactured goods through their indirect tax systems, spawned Congress to act quickly on the matter. As a result, Congress agreed to provide a deduction from taxable income equal to portion of the taxpayer's QPAI. This nine percent deduction will apply for taxable years starting in 2010. Until then, the deduction for taxable years beginning in 2005 and 2006 is three percent. For taxable years beginning in 2007 through 2009 is equivalent to a six percent deduction.

The deduction was set-up to apply to a variety of industries, which may not typically be considered manufacturing or production activities. With this new deduction, numerous accounting issues arise, such as 1) upgrading and customizing internal accounting and tax information systems to help assist apportioning gross receipts derived from transactions between DPGR and other income in order to comply with Section 199 requirements. 2) Help tracking tax basis on COGS in order to yield the most beneficial tax result under Section 199. 3) This may also alter how future sales contracts need to be negotiated in order to take into consideration Section 199 requirements, as well. For instance, contracts drawn up that will generate revenue from embedded services, such as installation or warranty that is not DPGR should be separately stated in the contract showing the sales of property and the services to be provided. 4) Businesses that manufacture or produce compact discs ("CDs"), DVDs, or other tangible medium to which qualified films or sound recordings are being affixed to the medium by a third party will have to be required to break-out the revenue earned between the sales attributable to the manufactured or produced medium and the third party developing and affixing the qualified films or sound recordings to the medium. 5) Taxpayers in the construction industry that generate DPGR from construction activities in the U.S. have to be concerned with the complexity of the allocation rules for cost of goods sold on real property construction projects. The safe harbor rules concerning the cost of land sold with the constructed home need to be considered. A safe harbor is provided for taxpayers whose

\footnotetext{
${ }^{158} I d$.

${ }^{159}$ Regs. $11.199-9(\mathrm{e})(2)$.
} 
gross receipts are predominately domestic production gross receipts. Therefore, if less than five percent ("5 \%") of their gross receipts are from non-qualifying receipts, they are not required to allocate gross receipts. More importantly, given there are complex requirements and discipline compliance with Section 199, taxpayers may not want to dedicate time and money to comply with such provisions and its cost allocation rules, and thus may choose or elect the small business overall method of allocating costs to DPGR. 6) With a pass-through entity, the deduction is computed at the individual level, not at the entity level. The deduction is equal to the lesser of adjusted gross income or QPAI. The deduction is limited to fifty percent (" $50 \%$ ") of wage expense.

Taxpayers have a planning opportunity. They can choose which method is most advantageous in calculating W-2 wages for purposes of the Section 199 deduction limitation. Again, there is not any formal written election required. It has to be selected on an annual basis. The major planning technique here is looking at which method to use in the upcoming year to determine the W-2 wages that yields the highest amount of Section 199 wages. Any payments made to independent or sub-contractors and sole proprietors, including guaranteed payments to partners are not considered to be W-2 wages, and are therefore excluded for purposes of determining the limitation on the deduction.

Business engaged in qualifying production activities should be aware of the tax advantages and disadvantages of the deduction. The deduction may be beneficial, and may affect a taxpayer's tax planning for taxable years beginning in 2005 and thereafter. Although Section 199 added considerable complexity to the tax law, it is ultimately an added tax benefit that will be appreciated by businesses involved in qualifying production activities.

\section{NOTES}




\section{NOTES}

